\title{
Cytotoxic, anti-mitotic and cytogenetic effects of the leaves and stems of Olax subscorpioidea Oliv. (Olacaceae) against Artemia salina nauplii and Allium cepa meristematic cells
}

\author{
Akolade R. Oladipupo ${ }^{1}$, Chinwe S. Alaribe ${ }^{1}$, Idris A. Ariyo ${ }^{1}$, Herbert A.B. Coker ${ }^{1}$, \\ Adeniyi S. Ogunlaja ${ }^{2}$ \\ ${ }^{I}$ Department of Pharmaceutical Chemistry, Faculty of Pharmacy, University of Lagos, \\ Lagos, Nigeria \\ ${ }^{2}$ Department of Chemistry, Nelson Mandela University, Port Elizabeth, South Africa
}

Received: July 2019; Accepted: August 2019

\begin{abstract}
The search for novel, safe and effective anticancer agents has been a continuous and recurring objective in cancer research. Olax subscorpioidea is a medicinal plant used for ethnomedicinal treatment of cancer in Nigeria. In this study, we investigated the cytotoxic, anti-mitotic and cytogenetic effects of methanol extracts of the leaves and stems of $O$. subscorpioidea. The cytotoxic activities were evaluated against brine shrimps (Artemia salina) nauplii and Allium cepa roots, while anti-mitotic and cytogenetic effects were assessed on Allium cepa meristematic cells. Cytotoxicity assays showed that the extracts demonstrated potent cytotoxic activities, having $\mathrm{LC}_{50}$ values of 10.7 and $45.2 \mu \mathrm{g} / \mathrm{mL}$ against brine shrimps and $\mathrm{IC}_{50}$ values in the range of $47.03-81.93 \mu \mathrm{g} / \mathrm{mL}$ on $A$. cepa roots. These activities were comparable to that of potassium dichromate and methotrexate used as positive control in each of the assays. Anti-mitotic results indicated that at a concentration of $10 \mu \mathrm{g} / \mathrm{mL}$, the extracts demonstrated percentage mitotic inhibition (\% M.I) of 35.95 - 70.12\%, with greater or similar anti-mitotic effects to methotrexate at a concentration of $125 \mu \mathrm{g} / \mathrm{mL}$, \% M.I of 39.04 - 40.64\%. Cytogenetic investigation revealed that the extracts showed chromosomal aberrations that were not considerably different from those observed in the negative control group. The current findings suggest that the plant extracts may contain cytotoxic and anti-mitotic compounds. Further research to investigate these extracts in more sophisticated test systems and to isolate and characterize their active principles is ongoing.
\end{abstract}

Keywords: Olax subscorpioidea, cancer, cytotoxicity, anti-mitotic, Allium cepa, Brine shrimp

\section{Introduction}

Cancer constitutes a major obstacle to human development and well-being. Latest statistics indicate that, two out of ten people; one in five men and one in six

\footnotetext{
*e-mail: salaribe@unilag.edu.ng
}

women, will develop cancer in their lifetime, while two out of twenty people; one in eight men and one in eleven women, will die from this morbid disease (Bray et al., 2018). Globally, cancer incidence and mortality are estimated to have risen to 18.1 million new cases and 9.6 million deaths in 2018 (Bray et al., 2018). According to the World Health Organization (WHO), $30-50 \%$ of these cases can be prevented and as a result, cancer prevention is 
identified as being central to reducing or reversing the rise in cancer burden (Chan, 2014). This sentiment is shared by the United Nations, which described cancer prevention as the cornerstone of global cancer control (United Nations General Assembly, 2011). The need for improvement in preventive measures is important, particularly in low-income and middle-income countries (LMICs), in which $60 \%$ of cancer cases and $75 \%$ of cancer deaths were recorded, a disproportionate index as opposed to a mere $5 \%$ of global spending on cancer (Farmer et al., 2010).

To complement efforts dedicated towards cancer prevention, there is an urgent need for development of effective and safer treatment interventions for the affected. Currently, the major methods for the treatment of cancer are surgery, radiotherapy and chemotherapy. Each of these methods is plagued with various limitations (Arnon et al., 2001; Brydøy et al., 2007; Davila, 2006). Natural products, either as pure compounds or as standardized extracts, provide great opportunities for the development of alternative treatments for cancer management (Cosa et al., 2006). Folkloric investigation revealed that Olax subscorpioidea is used in Nigeria for ethnomedicinal treatment of cancer.

Olax subscorpioidea Oliv. is a shrub or tree of the family Olacaceae and is found across Nigeria, Senegal, Zaire and West Cameroun (Oladipupo et al., 2018). Extracts of different parts of $O$. subscorpioidea are used traditionally for treating snake bites, scorpion stings, venereal diseases, infectious diseases, mental illnesses, arthritis, rheumatism, diabetes mellitus, cancer, asthma and as febrifuge (Ibrahim et al., 2008; Soladoye et al., 2010; Sonibare and Gbile, 2008) The antinociceptive, anti-ulcer, anti-depressant, anti-protease and antimicrobial activities of the plant have been confirmed by scientific studies (Adeoluwa et al, 2014; Ayandele and Adebiyi, 2007; Oyedapo and Famurewa, 1995; Victoria et al., 2010). Phytochemical investigations have reported the presence of alkaloids, flavonoids, tannins, saponins, and glycosides in the leaves and stem of the plant (Abdulazeez et al., 2015; Ayandele and Adebiyi, 2007; Oyedapo and Famurewa, 1995; Victoria et al., 2010). Also, 9 compounds, including 9,12-octadecadienoic acid (Z, Z)- (linoleic acid) and $n$-hexadecanoic acid have been reported in the leaves of O. subscorpioidea (Oladipupo et al., 2018). In some cancer research, conjugated linoleic acids have been shown to reduce metastasis of cancers to lung tissue and $n$ hexadecanoic acid has been reported to strongly boost metastasis in mouse models of human oral cancer (Cesano et al., 1998; Pascual et al., 2017).

The present study investigates the in vitro cytotoxic, anti-mitotic and cytogenetic properties of the methanol extracts of the leaves and stems of $O$. subscorpioidea against Artemia salina nauplii and Allium cepa meristematic cells.

\section{Materials and methods}

\section{Collection and authentication of plants}

Fresh leaves and stems of $O$. subscorpioidea were collected from Sango-ota, Ogun State and were authenticated by Mr. Oyebanji at the Herbarium of the Department of Botany, University of Lagos, Akoka. Specimens of the plant were deposited and allotted voucher number LUH: 7562.

\section{Preparation and extraction of plants}

The collected plant materials were shade dried and pulverised. Each of the pulverised plant parts $(250 \mathrm{~g})$ was extracted by maceration for 3 days with $2 \mathrm{~L}$ of methanol. The macerates were filtered and the filtrates concentrated in vacuo on a rotary evaporator at $40{ }^{\circ} \mathrm{C}$. The obtained concentrates were oven-dried at $40{ }^{\circ} \mathrm{C}$ to yield $O$. subscorpioidea leaves methanol (OSLM) and $O$. subscorpioidea stems methanol (OSSM) extracts.

\section{Brine shrimp lethality assay (BSLA)}

Brine shrimp Hatch Mix (San Francisco Bay Brand, Inc., U.S.A.) containing $21 \mathrm{~g}$ of brine shrimp eggs and salt was poured into a small plastic container (hatching chamber) and $1 \mathrm{~L}$ of water was added. The hatching setup was left at room temperature for $48 \mathrm{~h}$ to allow the shrimp to hatch and mature as nauplii (larva). After hatching, the larvae were separated from the shells and un-hatched eggs by drawing through a Pasteur pipette. Stock solutions $(100 \mu \mathrm{g} / \mathrm{mL})$ of the extracts were prepared by dissolving $5 \mathrm{mg}$ of each extract in small portion of sea water and making up to $50 \mathrm{~mL}$ with the same solvent. From the stock, working solutions (50, 25, 10 and $5 \mu \mathrm{g} / \mathrm{mL}$ ) were prepared by dilution with sea water. Five $\mathrm{mL}$ of each solution was placed in a test tube. Ten nauplii were added to each test tube with a Pasteur pipette. A negative control was set up for sea water. Potassium dichromate $\left(\mathrm{K}_{2} \mathrm{Cr}_{2} \mathrm{O}_{7}\right)$ was used as a positive control and was prepared in the same concentrations as the test extracts. Each concentration was tested in triplicate. The experiment was maintained at room temperature for $24 \mathrm{~h}$. After $24 \mathrm{~h}$, the numbers of surviving shrimps were counted, the $\%$ mortalities were calculated and negative control correction was applied using the Schneider-Orelli's formula (Schneider-Orelli, 1947):

$$
\begin{aligned}
& \text { Corrected } \% \text { mortality } \\
& =\frac{\text { test } \% \text { mortality }- \text { control } \% \text { mortality }}{100-\text { control } \% \text { mortality }} \times 100
\end{aligned}
$$

The $\mathrm{LC}_{50}$, lethal concentration that kills $50 \%$ of the shrimps, was determined for each test sample from the plot of $\%$ mortalities against the log of concentrations.

\section{Viability test of Allium cepa}

Equal-sized onion (A. cepa-2n=16) bulbs of the purple variety were used for this study and procured from Oyingbo market in Lagos, Nigeria. They were air-dried for more than two weeks before the start of experiment. The viability assay was carried out according to the method of Fiskesjo (1993). Outer scales of the dried onion bulbs were removed before 
use and also dry brownish roots at the bottom were carefully scraped away without damaging the ring of root primordial. The peeled bulbs were immersed into distilled water for $48 \mathrm{~h}$ to determine the viable ones. The water was changed daily and those onions that sprouted properly were used to carry out the experiment while those with poor or no growth were discarded.

\section{Root growth inhibition assay}

The root growth inhibition assay was performed from 24 to $48 \mathrm{~h}$ exposure tests as previously described (Samuel et al., 2010). The viable onion bulbs were exposed directly to $10,25,50$ and $100 \mu \mathrm{g} / \mathrm{mL}$ aqueous solutions of the extracts. Methotrexate (MTX), prepared in concentration of $125 \mu \mathrm{g} / \mathrm{mL}$ was used as positive control while distilled water served as negative control. Each concentration was set-up in 5 replicates. The test solutions (30 $\mathrm{mL}$ each) were replaced every $24 \mathrm{~h}$ with fresh solutions. At the end of each exposure period, the length of the root bundle was measured for the onions in each group, and the root growth in each group was expressed as a percentage of the root growth in the negative control group. The $\mathrm{IC}_{50}$, the concentration which inhibited root growth by $50 \%$, was determined for each test sample from the plot of root growths \% against the log of concentrations.

\section{Cytological and anti-mitotic studies}

After 24 and $48 \mathrm{~h}$ of exposure, roots from each bulb were harvested for cytological study. The root tips were fixed in freshly prepared acetic:ethanol $(1: 3, \mathrm{v} / \mathrm{v})$. The fixed root tips were transferred to a glass slide, hydrolysed with a solution of $1 \mathrm{~N} \mathrm{HCl}$ for $3 \mathrm{~min}$ and the excess acid was blotted out neatly with a filter paper. The hydrolysed root tips were squashed on the slide, and macerated with a dissecting needle to enhance stain uptake and ensure spreading of the cells in a monolayer for easy microscopic examination. Two drops of acetic orcein stain was added to the squashed tip and left for 30 min to allow the stain penetrate the cells thoroughly (Fiskesjo, 1993). After staining, the slide was gently covered with a cover slip allowing the stain to spread evenly over the square parts of the cover slip and the excess stain was blotted out with a filter paper. The square edges of the cover slip were sealed with clean fingernail polish to prevent drying out of the preparation by the heat of the microscope as suggested by Grant (1982). The slides were viewed under a microscope using X100 objective. The different stages of cell division were counted and recorded. Scoring of the cells was taken from five microscopic fields for each of the different test sample and approximately 500 cells were observed in each slide. Photomicrographs of the cells were taken with Digital Microscope (DB2-180M).

Макед. фарм. билт., 65 (1) 3 - 10 (2019)

\section{Statistical analysis of data}

All values are reported as the mean \pm S.E.M. (standard error of mean). The values of the variables were analysed for statistically significant differences using the Student's t-test on Microsoft Excel 2010 ${ }^{\circledR}$ Data Analysis tools. Differences were considered significant at $P<0.05$.

\section{Results}

\section{Brine shrimp lethality assay}

The results of root growth inhibition study of the extracts of $O$. subscorpioidea leaves and stems using $A$. cepa assay are as presented in Fig. 2, which shows the root growth (\%) of A. cepa after 24 and $48 \mathrm{~h}$ treatment with the extracts at different concentrations and methotrexate. When compared to the negative control group, the extracts significantly inhibited root growth of $A$. cepa $(P<0.05)$, with $\mathrm{IC}_{50}$ values of 47.03 and $60.16 \mu \mathrm{g} / \mathrm{mL}$ for OSLM, while OSSM showed $\mathrm{IC}_{50}$ values of 71.87 and 81.93 $\mu \mathrm{g} / \mathrm{mL}$ after 24 and $48 \mathrm{~h}$ exposure, respectively. These activities were comparable to that of methotrexate which gave 33.2 and $45.6 \%$ root growths at $125 \mu \mathrm{g} / \mathrm{mL}$ for the same treatment periods.

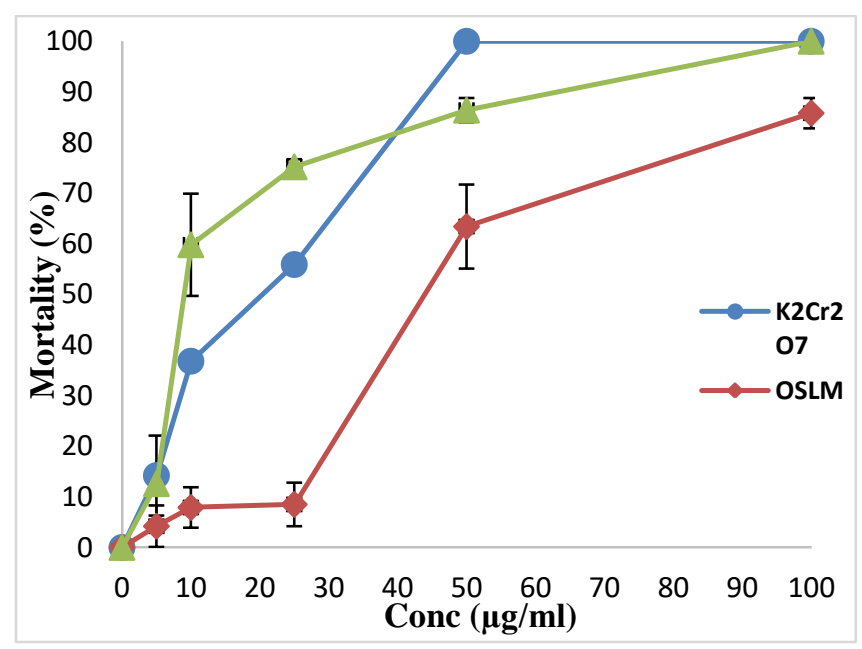

Fig. 1. Cytotoxic effect of O. subscorpioidea leaves (OSLM) and stems (OSSM) and Potassium dichromate (K2Cr2O7) on Brine shrimps.

\section{Root growth inhibition assay}

The results of root growth inhibition study of the extracts of $O$. subscorpioidea leaves and stems using $A$. cepa assay are as presented in Fig. 2, which shows the root growth (\%) of A. cepa after 24 and $48 \mathrm{~h}$ treatment with the extracts at different concentrations and methotrexate. When compared to the negative control group, the extracts significantly inhibited root growth of $A$. сера $(P<0.05)$, with $\mathrm{IC}_{50}$ values of 47.03 and $60.16 \mu \mathrm{g} / \mathrm{mL}$ for OSLM, while OSSM showed $\mathrm{IC}_{50}$ values of 71.87 and 81.93 $\mu \mathrm{g} / \mathrm{mL}$ after 24 and $48 \mathrm{~h}$ exposure, respectively. These activities were comparable to that of methotrexate which 
gave 33.2 and $45.6 \%$ root growths at $125 \mu \mathrm{g} / \mathrm{mL}$ for the same treatment periods.

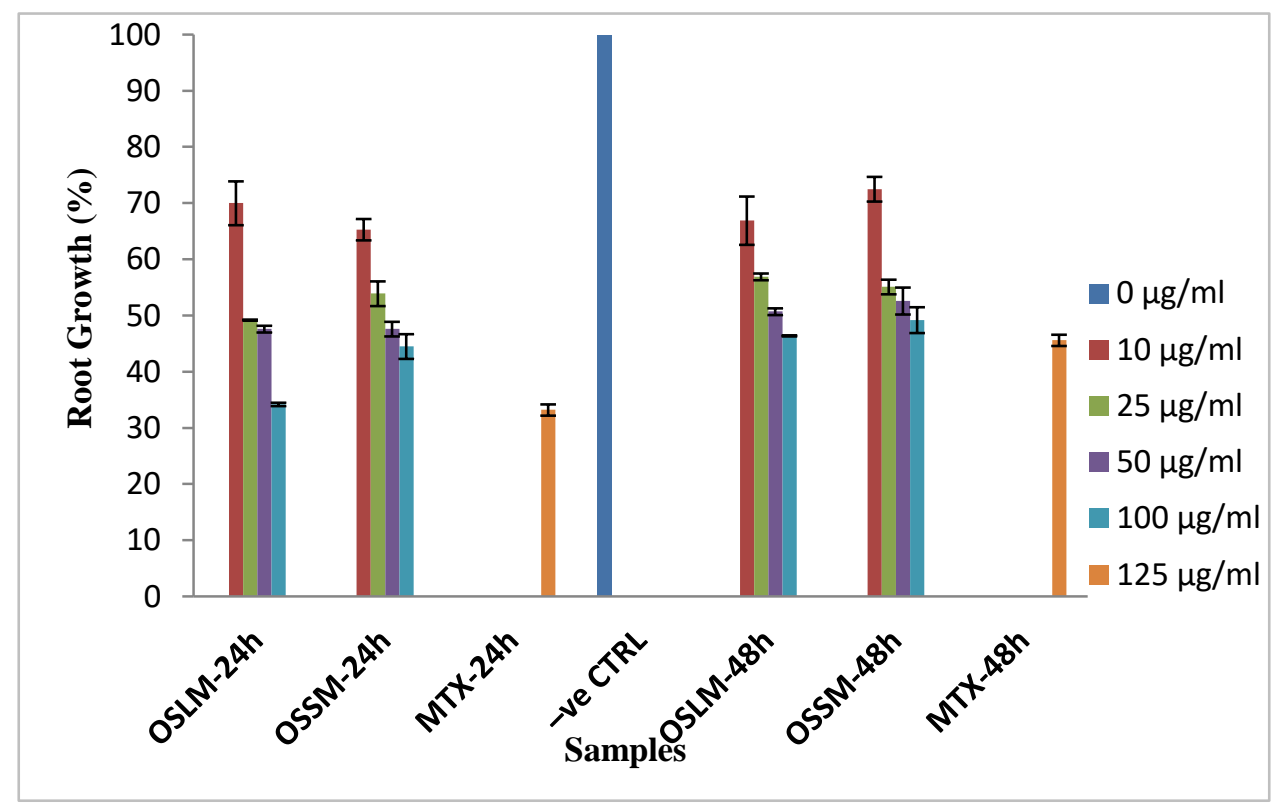

Fig. 2. Root growth (\%) of A. cepa treated with O. subscorpioidea leaves (OSLM) and stems (OSSM), methotrexate (MTX) and distilled water (-ve CTRL) after 24 and $48 \mathrm{~h}$.

\section{Cytological and anti-mitotic studies}

The results of cytological and anti-mitotic assays of the extracts of $O$. subscorpioidea leaves and stems are as presented in Fig. 3 and Fig. 4. Additionally, Fig. 3 shows the mitotic inhibition (\%) of the extracts and methotrexate at different concentrations on A. cepa after 24 and $48 \mathrm{~h}$ exposure while Fig. 4 give some representative photomicrographs of meristematic cells in A. cepa treated with the extracts and methotrexate at the end of the treatment period. Moreover, Table 1 shows the chromosomal aberrations consisting anaphase bridges (AB), laggards (L), vagrants (V), sticky or clumped chromosomes (SCC), other abnormal chromosomes (OAC) and total aberrations (TA).

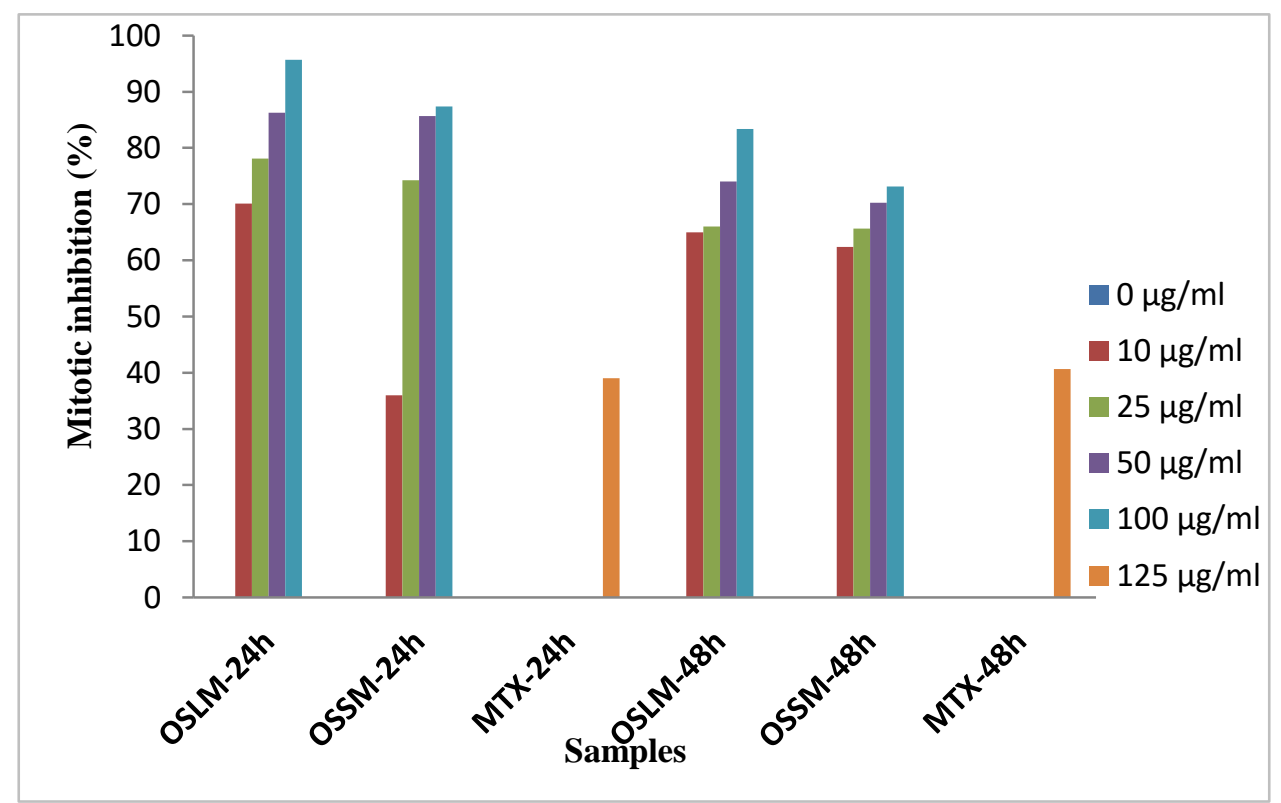

Fig. 3. Mitotic inhibition (\%) of O. subscorpioidea leaves (OSLM) and stems (OSSM) and methotrexate (MTX) after 24 and $48 \mathrm{~h}$. 
Table 1. Chromosomal aberrations in cells of A. cepa treated with O. subscorpioidea leaves (OSLM) and stems (OSSM) and methotrexate (MTX).

\begin{tabular}{|c|c|c|c|c|c|c|c|}
\hline \multirow[t]{2}{*}{ Sample } & \multicolumn{7}{|c|}{ Chromosomal aberrations } \\
\hline & $\begin{array}{c}\text { Conc } \\
(\mu \mathrm{g} / \mathrm{mL})\end{array}$ & $\mathrm{AB}$ & $\mathrm{L}$ & V & $\mathrm{SCC}$ & $\mathrm{OAC}$ & TA \\
\hline Control & - & $0 \pm 0$ & $0 \pm 0$ & $5 \pm 0$ & $0 \pm 0$ & $0 \pm 0$ & $5 \pm 0$ \\
\hline MTX & 125 & $2 \pm 2$ & $6 \pm 3$ & $14 \pm 0$ & $9 \pm 2$ & $8 \pm 2$ & $38 \pm 8$ \\
\hline \multirow[t]{4}{*}{ OSLM } & 10 & $0 \pm 0$ & $0 \pm 0$ & $0 \pm 0$ & $0 \pm 0$ & $0 \pm 0$ & $0 \pm 0$ \\
\hline & 25 & $0 \pm 0$ & $0 \pm 0$ & $1 \pm 1$ & $0 \pm 0$ & $1 \pm 1$ & $1 \pm 1$ \\
\hline & 50 & $1 \pm 0$ & $0 \pm 0$ & $0 \pm 0$ & $1 \pm 0$ & $0 \pm 0$ & $1 \pm 1$ \\
\hline & 100 & $1 \pm 1$ & $0 \pm 0$ & $0 \pm 0$ & $0 \pm 0$ & $0 \pm 0$ & $1 \pm 1$ \\
\hline \multirow[t]{4}{*}{ OSSM } & 10 & $1 \pm 1$ & $0 \pm 0$ & $0 \pm 0$ & $1 \pm 1$ & $1 \pm 1$ & $2 \pm 1$ \\
\hline & 25 & $1 \pm 1$ & $0 \pm 0$ & $0 \pm 0$ & $0 \pm 0$ & $1 \pm 0$ & $2 \pm 1$ \\
\hline & 50 & $0 \pm 0$ & $0 \pm 0$ & $0 \pm 0$ & $0 \pm 0$ & $0 \pm 0$ & $0 \pm 0$ \\
\hline & 100 & $1 \pm 1$ & $1 \pm 1$ & $0 \pm 0$ & $0 \pm 0$ & $0 \pm 0$ & $2 \pm 0$ \\
\hline
\end{tabular}

Values are mean \pm S.E.M ( $\mathrm{n}=5)$. Values with asterisk $(*)$ are significantly different from control (p < 0.05) AB: anaphase bridges; L: laggards; V: vagrants; SCC: sticky or clumped chromosomes;

OAC: other abnormal chromosomes

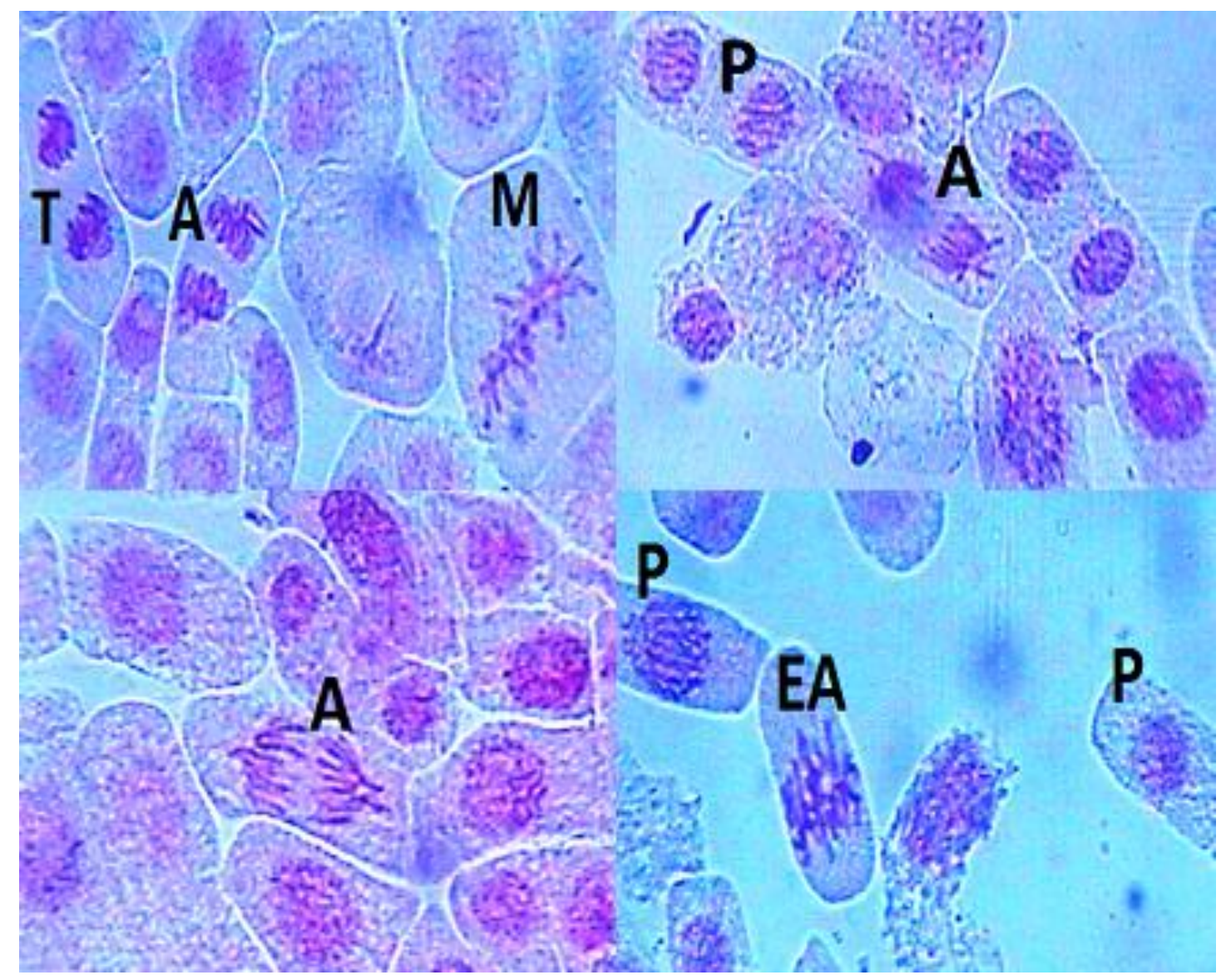

Fig. 4. Representative photomicrographs of A. cepa meristematic cells showing telophase (T), anaphase (A), metaphase $(\mathrm{M})$, prophase (P), and early anaphase (EA). Magnification X100. 


\section{Discussion}

Despite considerable progress in the understanding of the molecular basis of cancer, the ideal anticancer drug still remains elusive; thus, necessitating the continual and keen search for novel agents that could be useful in cancer management. As part of our ongoing research into the anticancer potentials of some indigenous plants that have ethnomedicinal use for cancer management, in this study, we investigated the cytotoxic, anti-mitotic and cytogenetic effects of methanolic extracts of $O$. subscorpioidea leaves and stems against brine shrimps and A. cepa meristematic cells.

The results of the evaluation of the cytotoxicity of the plant extracts by brine shrimp lethality assay (BSLA) are as presented in Fig. 1. The extracts showed a concentrationdependent lethality against brine shrimp. Extract of the stems, $\mathrm{LC}_{50}$ of $10.7 \mu \mathrm{g} / \mathrm{mL}$, showed higher potency than the leaves extract and potassium dichromate with $\mathrm{LC}_{50}$ of 45.2 and $13.0 \mu \mathrm{g} / \mathrm{mL}$ respectively. In a similar study, 5Fluorouracil (5-FU), one of the most frequently used anticancer drugs, gave an $\mathrm{LC}_{50}$ of $363 \mu \mathrm{g} / \mathrm{mL}$ on brine shrimps (Lawal et al., 2018). Our results revealed that the extracts of $O$. subscorpioidea leaves and stems showed greater potency than 5-FU. The BSLA is widely used for preliminary screening of plants for anticancer activity. $\mathrm{LC}_{50}$ values lower than $1000 \mu \mathrm{g} / \mathrm{mL}$ are regarded as considerably potent in this assay (Meyer et al., 1982).

The cytological and anti-mitotic effects of the plant extracts were investigated against $A$. сера. Since A. cepa cell cycle is completed in $24 \mathrm{~h}$ (Rank, 2003), the study was carried out at 24 and $48 \mathrm{~h}$ to investigate the mitotic and phase indexes in 2 consecutive cell cycle periods. The results of the root growth inhibition assay are as presented in Fig. 2. The extracts demonstrated a significant $(P<0.05)$ concentration- and time-dependent inhibition of A. cepa root growth when compared to the negative control. The leaves extract, $\mathrm{IC}_{50}$ of $47.03-71.87 \mu \mathrm{g} / \mathrm{mL}$, showed stronger inhibitory activity than the stems extract, $\mathrm{IC}_{50}$ of $60.16-$ $81.93 \mu \mathrm{g} / \mathrm{mL}$ across the $48 \mathrm{~h}$ period. At $100 \mu \mathrm{g} / \mathrm{mL}$, both extracts (root growth of $34.2-49.2 \%$ ) exerted comparable activity to the anticancer drug used as positive control, methotrexate (root growth of $33.2-45.6 \%$ at $125 \mu \mathrm{g} / \mathrm{mL}$ ).

In a similar manner to their inhibitory activity, the plant extracts demonstrated a significant concentration- and timedependent anti-mitotic effect. Anti-mitotic effect was estimated using mitotic index (M.I), a ratio of the number of cells undergoing mitosis to the total number of cells. The negative control, distilled water, showed M.I values of 35.24 - 35.45. The mitotic indices were significantly lower $(P<$ $0.05)$ in groups treated with $O$. subscorpioidea extracts and methotrexate, having M.I values of $1.53-22.67$ and $21.58-$ 21.04 respectively across the $48 \mathrm{~h}$ period. The results showed that the leaves extract; percentage mitotic inhibition (\% M.I) of $64.98-95.68 \%$, demonstrated higher anti-mitotic activity than the stems extract; \% M.I of $35.95-87.40 \%$. It was also observed that, at the lowest concentration, 10 $\mu \mathrm{g} / \mathrm{mL}$, both extracts, \% M.I of $35.95-70.12 \%$, showed greater or comparable anti-mitotic effects to methotrexate, $39.04-40.64 \%$ at $125 \mu \mathrm{g} / \mathrm{mL}$ across the treatment periods. The lower mitotic indices and high percentages of mitotic inhibition suggest that the plant extracts may inhibit cell proliferation by blocking cells in the mitotic phases of the cell cycle. This anti-mitotic activity of the plants extracts indicates a possible mechanism of cytostatic and cytotoxic actions similar to that of some existing plant-derived anticancer drugs, such as taxanes (paclitaxel and its derivatives) and vinca alkaloids (vinblastine, vincristine and their derivatives) (Stanton et al., 2011).

Chromosome aberrations, including anaphase bridges; laggards; vagrants; and sticky or clumped chromosomes were observed across the extracts, methotrexate and negative control groups. The aberrations observed in the extract-treated groups are comparable to the negative control group, indicating that they could have occurred spontaneously from errors in the normal processes of the cell.

\section{Conclusion}

Cancer remains a menacing disease to humanity. The need for novel effective and safer anticancer agents is still very important. This study investigated the cytotoxic, antimitotic and cytogenetic effects of methanol extracts of $O$. subscorpioidea leaves and stems. Comparative assessment of cytotoxic, anti-mitotic and cytogenetic results indicates that the plant extracts showed comparable effect to methotrexate, a well-known anticancer agent, even at lower concentrations. These findings may support the ethnomedicinal use of this plant in cancer treatment.

\section{Acknowledgements}

The authors are grateful to Mr. Akpan Utom-Obong of the Department of Cell Biology and Genetics, University of Lagos, for his technical assistance during the A. cepa assays.

\section{References}

Abdulazeez, I., Lawal, A.Y., Aliyu, S., 2015. Phytochemical screening and antimicrobial activity of the solvents' fractionated leaves extract of Olax subscorpioidea. J. Chem. Pharm. Res. 7(9), 22-26. Available at: https://doi.org/10.1080/14786419.2015.1005617.

Adeoluwa, O.A., Aderibigbe, A.O., Olonode, E.T., 2014. Antinociceptive property of Olax subscorpioidea Oliv (Olacaceae) extract in mice. J. Ethnopharmacol. 156, $353-$ 357. Available at: https://doi.org/10.1016/j.jep.2014.08.040.

Arnon, J., Meirow, D., Lewis-Roness, H., Ornoy, A., 2001. Genetic and teratogenic effects of cancer treatments on gametes and embryos. Hum. Reprod. Update. 7(4), 394-403. Available at: https://doi.org/10.1093/humupd/7.4.394.

Ayandele, A.A., Adebiyi, A.O., 2007. The phytochemical analysis and antimicrobial screening of extracts of Olax 
subscorpioidea. Afr. J. Biotechnol. 6(7), 868-870.

Bray, F., Ferlay, J., Soerjomataram, I., Siegel, R.L., Torre, L.A., Jemal, A., 2018. Global cancer statistics 2018: GLOBOCAN estimates of incidence and mortality worldwide for 36 cancers in 185 countries. CA Cancer J. Clin. 68(6), 394-424. Available at:

Brydøy, M., Fosså, S.D., Dahl, O., Bjøro, T., 2007. Gonadal dysfunction and fertility problems in cancer survivors. Acta Oncologica 46(4), 480-489. Available at: https://doi.org/10.3322/caac.21492.

Cesano, A., Visonneau, S., Scimeca, J.A., Kritchevsky, D., Santoli, D., 1998. Opposite effects of linoleic acid and conjugated linoleic acid on human prostatic cancer in SCID mice. Anticancer Res. 18, 1429-1434.

Chan, M., 2014. Foreword, in: Stewart, B.W., Wild, C.P. (Eds.), World Cancer Report 2014. The International Agency for Research on Cancer, Lyon, pp. 9.

Cosa, P., Vlietinck, A.J., Berghe, D.V., Maes, L., 2006. Antiinfective potential of natural products: How to develop a stronger in vitro 'proof-of-concept'. J. Ethnopharmacol. 106, 290-302. Available https://doi.org/10.1016/j.jep.2006.04.003.

Davila, M.L., 2006. Neutropenic enterocolitis. Curr. Opin. Gastroenterol. 22(1), 44-47. Available at: https://doi.org/10.3748/wig.v23.i1.42.

Farmer, P., Frenk, J., Knaul, F.M., Shulman, L.N., Alleyne, G., Armstrong, L. et al., 2010. Expansion of cancer care and control in countries of low and middle income: a call to action. Lancet 376, 1186-1193. Available at: https://doi.org/10.1016/S0140-6736(10)61152-X.

Fiskesjo, G., 1993. The Allium test in wastewater monitoring. Environ. Toxicol. Water Qual. 8, 291-298. Available at: https://doi.org/10.1002/tox.2530080306.

Grant, W.F., 1982. Chromosome aberration assays in Allium, a report of the US Environmental Protection Agency GENETOX Program. Mutat. Res. 99, 273-291. Available at: https://doi.org/10.1016/0165-1110(82)90046-X.

Ibrahim, J.A., Muazzam, I., Jegede, I.A., Kunle, O.F., Okogun, J.I., 2008. Ethnomedicinal plants and methods used by Gwandara tribe of Sabo Wuse in Niger state, Nigeria, to treat mental illness. Afr. J. Trad. Complement. Altern. Med. 4, 211-218. Available at: https://doi.org/10.4314/ajtcam.v4i2.31210.

Lawal, R.A., Lawal, S.K., Odesanmi, O.S., Isiaq, O., Adefisan, I.O, Badmus, I.A., 2018. Brine shrimp cytotoxicity and antimitotic activity of aqueous root-bark extract of Securidaca longepedunculata (Polygalaceae). Trop. J. Nat. Prod. Res. 2(3), 109-113. Available at: https://doi.org/10.26538/tjnpr/v2i3.1.
Meyer, B.N., Ferrigni, N.R., Putnam, J.E., Jacobsen, L.B., Nichols, D.E., McLaughlin, J.L., 1982. Brine shrimp: A convenient general bioassay for active plant constituents. Planta Med. 45, 31-34. Available at: https://doi.org/10.1055/s-2007-971236.

Oladipupo, A.R., Alaribe, C.S., Balogun, O.T., Akere, H.T., Ayanda, F.A., Toye, T.E., Coker, H.A.B., 2018. investigation of chemical, genotoxic and haematological properties of secondary metabolites from $n$-Hexane extract of Olax subscorpioidea Oliv. (Olacaceae) Leaves. Trop. J. Nat. Prod. Res. 2(12), 506-511. Available at: https://doi.org/10.26538/tjnpr/v2i12.3.

Oyedapo, O.O., Famurewa, A.J., 1995. Antiprotease and membrane stabilizing activities of extracts of Fagara. Zanthoxyloids, Olax subscorpioides and Tetrapleura tetraptera. Pharmacol. Biol. 33, 65-69. Available https://doi.org/10.3109/13880209509088150.

Pascual, G., Avgustinova, A., Mejetta, S., Martin, M., Castellanos, A., Attolini, C.S., Burenguer, A., Prats, N., Toll, A., Hueto, J.A., Bescos, C., Di Croce, L., Benitah, S.A., 2017. Targeting metastasis-initiating cells through the fatty acid receptor CD36. Nature 541, 41-45. Available at: https://doi.org/10.1038/nature20791.

Rank, J., 2003. The method of Allium anaphase-telophase chromosome aberration assay. Ekologija 1, 38-42.

Samuel, O.B., Osuala, F.I., Odeigah, P.G.C., 2010. Cytogenotoxicity evaluation of two industrial effluents using Allium cepa assay. Afr. J. Environ. Sci. Technol. 4(1), 021-027.

Schneider-Orelli, O., 1947. Entomologisches Praktikum Einfürung in die land- un forstwirtschafliche Insektenkunde. Aarau: Sauerländer \& Co.

Soladoye, M.O., Amusa, N.A., Raji-Esan, S.O., Chukwuma, E.C., Taiwo, A.A., 2010. Ethnobotanical survey of anti-cancer plants in Ogun state, Nigeria. Ann. Biol. Res. 1(4), 261-273.

Sonibare, M.A., Gbile, Z.O., 2008. Ethnobotanical survey of antiasthmatic plants in South Western Nigeria. Afr. J. Trad. Complement. Altern. Med. 5, 340-345. Available at: https://doi.org/10.4314/ajtcam.v5i4.31288.

Stanton, R.A., Gernert, K.M., Nettles, J.H., Aneja, R., 2011. Drugs that target dynamic microtubules: a new molecular perspective. Med. Res. Rev. 31(3), 443-481. Available at: https://doi.org/10.1002/med.20242.

United Nations General Assembly, 2011. Political Declaration of the High-level Meeting of the General Assembly on the Prevention and Control of Non-communicable Diseases, UN Doc A/66/L.1.

Victoria, U.C., Michael, U.C., Johnny, M.U., 2010. Evaluation of the antiulcer activity of Olax subscorpioidea Oliv. roots in rats. Asian Pac. J. Trop. Med. 3, 13-16. Available at: https://doi.org/10.1016/S1995-7645(10)60022-3. 
Резиме

\title{
Цитотоксични, анти-митотични и цитогенетски ефекти на листови и стебла на Olax subcorpioidea Oliv. (Olacaceae) против Artemia salina ларви и Allium cepa меристемски клетки
}

\author{
Аколаде Р. Оладипупо ${ }^{1}$, Чинве С. Аларибе ${ }^{1}$, Идрис А. Аријо ${ }^{1}$, \\ Херберт А.Б. Кокер ${ }^{1}$, Адениј С. Огунлаја ${ }^{2}$ \\ ${ }^{1}$ Оддел за фармацевтска хемија, Фармацевтски факултет, Универзитет Лагос, \\ Лагос, Нигерија \\ ${ }^{2}$ Оддел за хемија, Универзитет Нелсон Мандела, Порт Елизабет, Јужна Африка
}

Клучни зборови: Olax subcorpioidea, канцер, цитотоксичност, анти-митотичен, Allium cepa, солени ракчиња

Пребарувањето на нови, безбедни и ефективни антиканцерогени агенси е континуирана и повторлива цел во истражувањата на канцерогени состојби. Olax subcorpioidea е лековито растение што се користи за етнофармаколошки третман на канцерогени состојби во Нигерија. Во оваа студија, ги испитувавме цитотоксичните, анти-митотичните и цитогенетските ефекти на метанолни екстракти од листовите и стеблата на $O$. subcorpioidea. Цитотоксичните ефекти беа евалуирани со примена на солени ракчиња од видот Artemia salina и Allium сера корени, додека анти-митотичните и цитогенетските ефекти беа проценети врз меристемски клетки од Allium cера. Испитувањата за цитотоксичност покажаа дека екстрактите манифестираат силна цитотоксична активност со вредност на $\mathrm{LC}_{50}$ од 10,7 и $45,2 \mu \mathrm{g} / \mathrm{mL}$ против солени ракчиња и $\mathrm{IC}_{50}$ вредности во опсегот од 47,03 $81,93 \mu \mathrm{g} / \mathrm{mL}$ на корените на A. сера. Добиените резултати се споредливи со оние за калиум дихромат и метотрексат што се користени како позитивни контроли. Процентуалната митотична инхибиција (\% М.I) од 35,95 - 70,12\% за екстрактите во концентрација $10 \mu \mathrm{g} / \mathrm{mL}$ покажаа дека имаат споредлив антимитотични ефекти како и позитивната контрола метотрексат, што покажа вредност од 39,04 - 40,64\% при концентрација од $125 \mu \mathrm{g} / \mathrm{mL}$. Цитогенетското испитување покажа дека екстрактите предизвикуваат хромозомски аберации кои не се разликуваат во голем степен од оние забележани во негативната контролна група. Тековните наоди сугерираат дека испитуваните екстракти може да содржат цитотоксични и анти-митотични соединенија меѓутоа испитувањето на овие екстракти со примена на пософистицирани тест системи за изолирање и карактеризирање на нивните активни принципи е сѐуште во тек. 